\title{
15 COVID-19 in the Mexican federation
}

\author{
Managing the health and \\ economic crises
}

\author{
Laura Flamand, Monica Naime and \\ Juan C. Olmeda
}

\subsection{Introduction}

The federal system in Mexico has responded in a relatively uncoordinated fashion to the health and economic crises caused by the spread of COVID-19. There are two significant structural reasons for this: the centralized, asymmetrical nature of the federal system, and the fragmentation of healthcare services.

Mexico is facing a dire crisis in its healthcare system and its economy during the pandemic. The case fatality rate of Mexico has been the highest in the region since May 2020 and the world's second highest since October 2020 (Roser et al. 2020). In economic terms, the GDP contracted around 9.1 percent in 2020 (BBVA Research 2021). Mexico's three orders of government implemented uncoordinated policies to fight these crises between March and December 2020. These actions led to growing tensions in the Mexican federation after the first ten months of the pandemic.

Without clear federal guidelines and standards to manage the crisis, state governments have reacted unevenly, deepening social inequalities. Because relatively affluent states have more capable governments and more robust health systems, their populations have been protected more effectively than those of the poorest states (Table 15.1).

\subsection{COVID-19 in Mexico}

The first case of COVID-19 in Mexico was confirmed on 27 February 2020, and the first two deaths occurred on March 18. Since then and until 31 December 2020, according to government statistics, COVID-19 has taken more than 131,190 lives, with more than 1,486,313 confirmed cases (CONACYT 2020). This means 975 deaths and 11,060 cases per 1 million inhabitants. The observed case-fatality ratio in Mexico more than triples that of the United States, Argentina, and Brazil (Roser et al.

Table 15.1 Key Statistics on COVID-19 in Mexico as of 10 January 2021

\begin{tabular}{lllll}
\hline $\begin{array}{l}\text { Cumulative } \\
\text { Cases }\end{array}$ & $\begin{array}{l}\text { Cumulative Cases per } \\
100,000 \text { Population }\end{array}$ & $\begin{array}{l}\text { Cumulative } \\
\text { Deaths }\end{array}$ & $\begin{array}{l}\text { Cumulative Deaths per } \\
100,000 \text { Population }\end{array}$ & $\begin{array}{l}\text { Case Fatality } \\
\text { Percentage }\end{array}$ \\
\hline $1,507,931$ & $1,169.5$ & 132,069 & 102.4 & 8.8
\end{tabular}

Source: World Health Organization Weekly epidemiological update - 12 January 2021. Geneva: WHO, 2021. Available from https://www.who.int/publications/m/item/weekly-epidemiological-update 


\section{Laura Flamand et al.}

2020). ${ }^{1}$ The general situation deteriorated further by the beginning of 2021 , when the daily number of new cases and deaths set new records and reached higher figures than those observed during 2020.

The accuracy of these figures has been questioned considering the rather low number of tests completed in the country. Worldwide, Mexico is the country testing the least, with two or fewer tests performed for every confirmed case (JHU 2020). Healthcare workers have been especially vulnerable during the pandemic: 13 percent of the confirmed cases are nurses and physicians, and Mexico leads the world statistics with the highest death toll among healthcare workers with 2,400 (Amnesty International 2020; Montes 2021).

The severe effects of COVID-19 in Mexico must be set into the context of a fragile health system when compared with other countries for many reasons. First, the public health system is fragmented in two large and deeply unequal subsystems. One system protects people with contributory social security protection. The second system takes care of those lacking such coverage, approximately six out of ten people. The per capita public health expenditure is 39 percent higher for the group of insured people compared to those uninsured (SS 2019). Second, public health expenditure is extremely low in Mexico, amounting to approximately 2.8 percent of GDP compared to 6.6 percent in Argentina and 4.0 percent in Brazil. Third, the proportion of out-of-pocket expenditures in Mexico (41 percent) is considerably larger than in other countries of the region such as Argentina (15 percent) and Brazil (28 percent). Fourth, the Mexican health system operates with an enormous deficit in human resources. In order to reach the median of the OECD countries, 120,000 additional physicians would need to graduate and enter the health care system (Flamand 2020).

Apart from the health toll, the pandemic has also severely affected the highly open Mexican economy. The GDP dropped in the second quarter of 2020 by 17.1 percent compared to the previous quarter (INEGI 2020a), making this shock twice as strong as the economic crisis of 2009 and the tequila crisis of 1994 (see Figure 15.1).

This general slowdown of the economy resulting from restrictions on mobility was accompanied by major drops in three crucial productive sectors: exports, tourism,

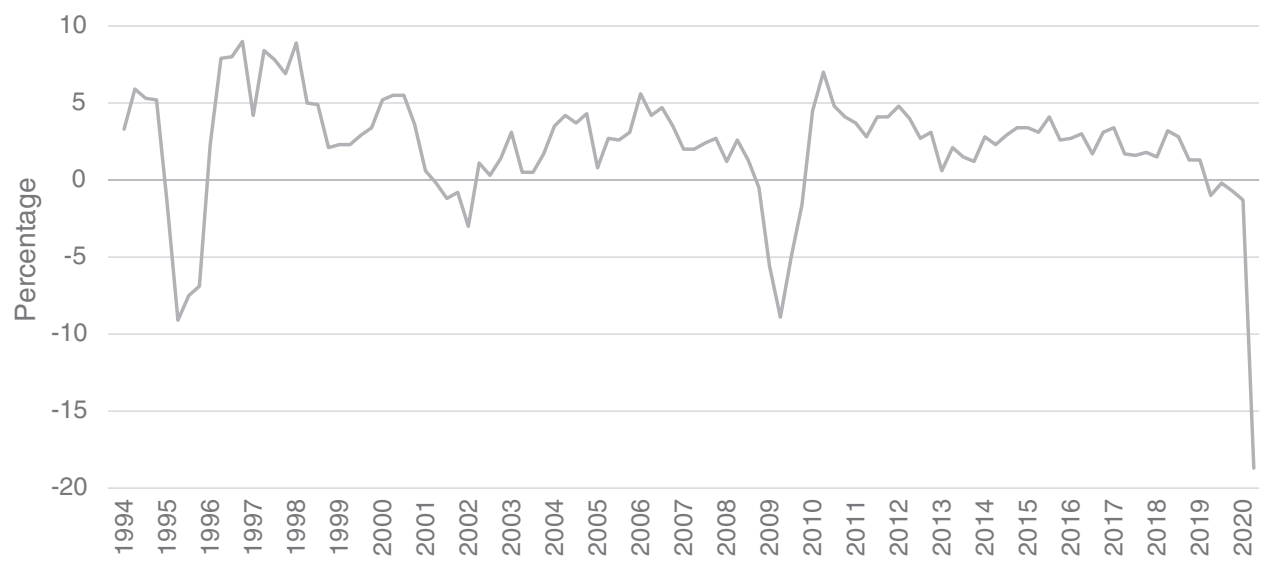

Figure 15.1 Annual Variation of the Quarterly GDP in Mexico.

Source: Prepared by the authors with information from INEGI 2020a. 
and oil. First, due to the abrupt slowdown in the American and Chinese economies, the demand for exports has diminished considerably (World Bank 2020; IMF 2020). Second, the tourism sector has plummeted with severe consequences in terms of employment. This sector accounts for nearly 16 percent of both jobs and GDP (Mooney and Zegarra 2020). Third, with borders closed and travel restricted, the price of the Mexican oil blend dropped 57 percent in April 2020 compared to the prices in December 2019 (Bank of Mexico 2020).

These disturbances have meant that the peso depreciated 15 percent from January to August 2020 (IMF 2020). Also, 4.4 million people have lost their jobs during the second quarter of the year (INEGI 2020b). This increase in unemployment is significantly above the levels of the 2008 financial crisis and is not expected to return to pre-crisis levels until the middle of 2021 (OECD 2020). Of those who have lost their jobs due to this unprecedented crisis, 71 percent worked in the tertiary sector, and 92 percent do not have access to the health care system (INEGI 2020c).

The pandemic is likely to deepen inequalities around the world, as predicted in several studies. This is especially relevant in a country as unequal as Mexico. The economic and health costs of the pandemic are differentiated, not only by economic sector but also by geography, income, and gender. Metropolitan areas have been more extensively impacted than rural areas for two reasons. First, the density of the population allows easier transmission of the infection. Second, mobility restrictions have lasted longer in metropolitan areas. In terms of income, the case-fatality ratio is twice as high in the poorest municipalities than in the richest ones (CONEVAL 2020a), and it is estimated that up to 10.7 million people will fall below the extreme poverty line (CONEVAL 2020b). Finally, in terms of gender, compared to the same period in 2019, the number of violent deaths of women has increased 12 percent and that of emergency calls for domestic violence 53 percent (INMUJERES 2020). In addition, according to official estimates, close to 150,000 unwanted pregnancies are to be expected and at least 21,500 additional teenage pregnancies (CONAPO 2020). This brief account highlights the deep and long-lasting impact that COVID-19 will have on the economic and health crisis in Mexico.

\subsection{COVID-19 and federalism in Mexico}

Mexico is a federal republic composed of the central government and 32 subnational units: 31 states and Mexico City. Federalism was formally proclaimed as a form of government in 1824 when the first Mexican Constitution was enacted after independence. However, federalism was later abandoned because of internal fights for the control of power during most of the 19th century. It was not until 1917, after the Mexican Revolution, that a new Constitution was adopted, and federalism became again the de jure form of organization. ${ }^{2}$

Nevertheless, the evolution of Mexican federalism was not linear during the 20th century. Until the 1980s, the country remained highly de facto centralized given that the political system was dominated by a single political party which controlled almost all elected positions. The situation began to change in the last decades of the 20 th century because of both democratization and decentralization. Democratization happened when opposition parties began to win electoral contests at the local level. Decentralization took place when the federal government devolved responsibilities to states and municipalities. Several recentralizing measures have been implemented 


\section{Laura Flamand et al.}

since the beginning of the 21st century, mainly as an attempt to solve coordination problems that emerged in the post-decentralization scenario (Olmeda and Armesto 2017).

Mexican subnational governments enjoy a certain level of autonomy since constitutionally they can enact their own norms and legal regulations and have responsibility over several policy areas. Fiscally, however, they are highly dependent on federal transfers: on average, only 10 percent of the total income of subnational governments results from local taxes. This fact is crucial for understanding how the characteristics of the Mexican federal system have permeated the response of both the national and subnational governments to the COVID-19 crisis.

As per the federal Constitution, public health is a shared responsibility of federal, state, and municipal governments. In addition, as we have already mentioned, the health care system is de facto deeply fragmented. There are several subsystems providing care for formal sector workers, government employees, oil workers, and the armed forces. Furthermore, since the beginning of 2020, the National Institute of Health for Wellness (INSABI) had pledged to provide complete coverage for an ample list of health interventions and medicines to those in the informal economy (six out of ten workers). Unfortunately, when COVID-19 arrived in Mexico, the Institute was operating without formal rules and with insufficient funds for such a large and ambitious task. Mexico has traditionally spent rather meagerly on health care, 5.5 percent of GDP compared to the average in the OECD countries of 8.8 percent including both private and public expenditures. Furthermore, the quantity and quality of health care facilities in Mexico vary enormously across the states. Thus, poor uninsured people in the states with weak health care structures are exposed to the highest risk.

The Mexican Constitution provides for extraordinary public health actions in the case of emergencies. The Ministry of Health is mandated to immediately take the necessary measures with the agreement of the President to prevent and control risks in specific parts of the territory for definite periods in such cases. These federal measures include the assignment of tasks to federal, state, or municipal authorities as well as to health professionals, including measures related to public gatherings; air traffic and maritime and land transit; free use of telephonic, telegraphic, and mail media as well as radio and television transmissions; and any other determined by the Ministry. This, however, does not imply that subnational governments relinquish their legal powers regarding the implementation of health security measures. Rather, when facing health emergencies, the responsibilities of state governments in Mexico are determined by the legal regulations regarding local public health in their territory, those assigned by the Ministry of Health given the extraordinary public health actions and, finally, those established by the National Public Health Council.

Three weeks after the first case was confirmed in Mexico, on 19 March 2020, the National Public Health Council met and declared the pandemic a health emergency. This declaration is not equivalent to a state of emergency in the sense that it gives special powers to the executive, but rather provides a mandate for prioritizing its attention to the matter. The declaration of the health emergency allowed for the adoption of health, economic, and fiscal measures. At the federal level, up to August 14, the government had adopted 53 measures to respond to the sanitary, economic, and social impact of the pandemic (CEPAL 2020). The first measure was for the President to approve the reallocation of up to 0.7 percent of the GDP to an emergency fund to face the pandemic. The federal government also adopted specific measures strengthening 
the health system to control the disease, including adapting public hospitals toward COVID-19 services, expanding the public network with the inclusion of private hospitals, and importing the essential equipment required to care for patients effectively.

The federal government has argued that caution was needed when halting the economy because poor people needed to be protected, mainly those living on a daily subsistence income. This is especially relevant as close to 60 percent of people work in the informal economy and thus are excluded from contributory social security. The federal government has not expanded social assistance, nor deferred or reduced taxes (Lustig et al. 2020). Consequently, people in the informal economy continued working, thus increasing the probability of getting infected by the virus, while they only had access to poorly equipped and resourced health facilities, that is, those available via the newly created INSABI.

On 23 March 2020, the National Public Health Council declared a "National Campaign of Healthy Distancing" which suspended in-person education activities. The campaign also recommended vulnerable employees to stay away from their workplaces and strongly encouraged the population overall to stay at home (SS 2020). However, no mandatory mobility restrictions were imposed across the country, and flights were not cancelled, although the US-Mexico border was closed for any nonessential travel. On March 23, the federal Ministry of Education decided to cancel in-person instruction for the entire education system across the country (SEP 2020). By that time, however, 10 out of the 31 state governments plus Mexico City had already canceled school activities in their territories (Excelsior 2020).

A general trend from the beginning of the crisis was that the state governments adopted their own measures to face the pandemic because the federal authorities were not acting fast enough. In addition to cancelling classes, approximately 10 out of the 32 states closed bars, restaurants, museums, and beaches earlier than these closures were proposed by the federal authorities. Yucatán went as far as to impose fines for people not following confinement regulations; Chihuahua suggested that people who had tested positive for COVID-19 may even face jail time if they failed to abide by the confinement requirements. In Jalisco, state authorities pushed for adopting their own testing policies, arguing that the federal government was not performing enough tests.

This proactive approach by state governments was consistent in the early months. At the state level, responses were quicker, more numerous and rather heterogenous. Between March 1 and 31 July 2020, 629 measures were adopted by state governments to manage the dire health and economic consequences of the pandemic (Cejudo et al. 2020). All states adopted measures restricting work and movement, and most of them implemented food support programs. The economic relief programs devised by state governments ranged from wage subsidies plus cash transfers to deferrals and discounts on taxes for both individuals and businesses. In addition, tax inspections have been postponed (OECD 2020). Almost half of these measures were fully financed with resources from state governments coffers (Cejudo et al. 2020). ${ }^{3}$ States governed by parties in opposition to the President have been the most active in adopting measures to deal with the crisis.

At the municipal level, a much lower number of measures have been adopted: 159 municipalities in 25 out of 32 states have adopted specific initiatives (CONAMER 2020). Although the legal framework limits the role of municipal governments in health and sanitary services, and they cannot impose preventive health measures, 
cities and towns found other ways to act. Municipalities do have legal competences for regulating public spaces (i.e., markets, parks, and graveyards), water provision and treatment as well as waste management. With these legal mandates, municipalities have adopted 371 measures ranging from fiscal stimuli to prohibition of massive events combined with mandatory lockdowns of questionable legality.

There is an emerging consensus that the lack of coordination is the defining characteristic of the actions and emergency plans adopted by different levels of government in Mexico. Coordination is absent both in vertical relations (among federal, state, and municipal governments) and in horizontal ones (i.e., agreements across ministries at the same level of government). Intergovernmental cooperation was reached only partially in specific areas; for example, 7 out of 32 state governments announced the adoption of a common scheme for the reopening of their economies on May 29 (Najar 2020).

\subsection{Is the Mexican federal system different because of the COVID-19 pandemic?}

Considering the general situation described in the previous sections, three points should be stressed regarding the effects of the COVID-19 pandemic in the Mexican federal system. First, there are key differences between the actions adopted by the federal government and those promoted by state authorities. These differences emerged in the types of instruments used, and the population targeted, especially when addressing the economic consequences of the pandemic. The federal government used existing social programs and focused on individuals who were already receiving social benefits. State governments, however, created new instruments overnight and attempted to care for a more heterogeneous group of citizens.

Second, the lack of coordination slowly evolved into an open political conflict between federal authorities and several governors from parties in opposition to President López Obrador and his political party, Morena. The governor of Jalisco, Enrique Alfaro, accused federal authorities of mismanaging the COVID-19 crisis and of blocking the massive implementation of fast testing devised by his own state government. Later, Governor Alfaro accused the federal Ministry of Health of manipulating the COVID-19 statistics so the ministry could extend social distancing measures, thus punishing Jalisco by slowing down the reopening of the state economy. The governor of Chihuahua, Javier Corral, became a vocal actor in opposition to the federal economic recovery plan, arguing that financial aid was not sufficient. In a more dramatic move in the same vein, at the end of July, nine governors signed an open letter asking for the resignation of Hugo López-Gatell, the federal Vice-Minister of Health and the leading tactician of the federal government plans to fight the pandemic, accusing him of failing to control the disease.

In addition, and as a response to the uncertainty faced by state governments given the severe decrease in national and subnational tax collection, a group of governors called for a revision of the fiscal pact, in place since 1978. States currently have limited fiscal alternatives to obtain additional resources, as the amount of debt they may accrue is capped by federal regulations (CIEP 2020). The ultimate crisis in the Mexican federation occurred at the beginning of September when ten governors left the National Conference of Governors, an organization created in the early 21st century to coordinate state governments' actions when negotiating with the federal authorities on a variety of policy issues (Flamand 2010). 
Third, the uneven reaction of state governments to the pandemic may be explained by their asymmetric nature (i.e., in terms of financial resources and bureaucratic capabilities) and thus appears to have deepened social inequalities. That is, relatively affluent states tend to have more capable governments and more robust health systems and therefore have been able to deal with the crisis in a more effective manner than the poorest subnational units. This may explain the much higher fatality rate in poorer municipalities than in richer ones.

On May 14, the federal government announced the "New Normality," a plan presenting state and municipal level reopening scenarios. It included the opening of 324 "municipalities of hope" the following week (SE 2020). Three weeks after the announcement, only 60 municipalities remained open, as the pandemic continued to spread (Ariadna Ortega 2020). By the beginning of September, Mexico was already returning to pre-pandemic levels of mobility. In fact, at the beginning of that month, one quarter of states had reopened all activities, except for in-person education. At the same time, the number of tests remained low in the country: while the World Health Organization recommends performing at least 20 tests for every positive case before relaxing social distancing measures (WHO 2020), in September, the number for Mexico was 2.4 tests for every positive case (Hasell et al. 2020).

In Mexico, there have been complex and close interactions between electoral politics on one hand, and the policies developed to contain contagions and to alleviate the economic effects of the pandemic on the other. A prime example is the policy differences between the federal government of president López Obrador and the government of Mexico City headed by Claudia Sheinbaum. They were both elected under the banner of the same political party, Morena. ${ }^{4}$

Since the beginning of the pandemic, the government of Mexico City has implemented policies to safeguard the incomes of workers and businesses, in contrast to the lackluster stimulus packages advanced by the federal government. This was a bold move considering the massive financial dependence of the states on federal grants.

Regarding the closing of nonessential activities in mid-March and mid-December of 2020, several news articles have reported clashes between López Obrador and Governor Sheinbaum in private despite a show of unity in public. Governor Sheinbaum apparently insisted on closing earlier to prevent further contagions on both occasions. Given the importance of the activity of the city for the economic performance of Mexico overall, federal officials strongly opposed early closures, apparently causing the highest levels of occupation of hospitals beds and of deaths associated with COVID-19 in late January 2021.

The federal system in Mexico has responded in a somewhat uncoordinated fashion to the health and economic crises caused by the spread of COVID-19. There are two significant structural reasons for this. The first is the centralized and asymmetrical nature of the federal system. The second is the fragmentation of the healthcare system. However, without clear federal guidelines and standards to manage the crisis, state governments have reacted unevenly, deepening social inequalities. The result was that isolated decision-making, disconnected fluxes of information, and uncoordinated actions all deepened public uncertainty. The Mexican federal government has failed to take a vigorous leadership during this crisis. The result is that resources have been used inefficiently, and severe problems have arisen in implementing the policies designed to protect the Mexican population from COVID-19. 


\section{Notes}

1 According to data collected by the Coronavirus Resource Center of Johns Hopkins University \& Medicine (2020), the case-fatality ratio for Mexico is the second highest in the world, reaching 8.5 percent and only surpassed by Yemen. The value for Brazil and Argentina is 2.5 percent and for the US 1.7 percent.

2 Three further constitutions were enacted by Mexico in 1835, 1843 and 1857. In the first two cases, they imposed a centralized form of government.

3 According to data collected by Cejudo et al. (2020): 47 percent of the state actions to combat Covid-19 were completely state funded; 10 percent were financed by the state government in cooperation with the federal or municipal orders, civil society organizations or private funding; 3 percent do not have state funding; and for 39 percent the source of funding is unknown.

4 Sheinbaum is also one of the forerunners for the next presidential election in 2024. In Mexico, after serving one term neither the president nor any governor may be reelected.

\section{Bibliography}

Amnesty International, 2020. Exposed, Silenced, Attacked: Failures to Protect Health and Essential Workers during the COVID-19 Pandemic. London: Amnesty International. Available from: https://www.amnesty.org/en/documents/pol40/2572/2020/en/ [Accessed 7 February 2021].

Ariadna Ortega, 2020. Mapa COVID: en tres semanas, los municipios de la esperanza bajaron de 300 a 60. Ciudad de México: Expansion, 14 June. Available from: https:// politica.expansion.mx/estados/2020/06/14/mapa-covid-en-tres-semanas-los-municipiosde-la-esperanza-bajaron-de-300-a-60 [Accessed 7 February 2021].

Bank of Mexico, 2020. Precio de la mezcla mexicana de petróleo [online]. Mexico City: Bank of Mexico Available from: https://www.banxico.org.mx/apps/gc/precios-spot-del-petroleogra.html [Accessed 3 September 2020].

BBVA Research, 2021. Mexico Economic Outlook. First Quarter 2021. Mexico City: Banco Bilbao Vizcaya Argentaria (BBVA). Available from: https://www.bbvaresearch.com/en/ publicaciones/mexico-economic-outlook-first-quarter-2021/ [Accessed 7 February 2021].

Cejudo, G.M., Gómez-Álvarez, D., Michel, C.L., Lugo, D., Trujillo, H., Pimienta, C. and Campos, J., 2020. Federalismo en COVID: ¿Cómo responden los gobiernos estatales a la pandemia? Versión 4. Ciudad de México: Centro de Investigación y Docencia Económicas (CIDE). Available from: https://www.researchgate.net/publication/341680758_Federalismo_en_COVID_Como_responden_los_gobiernos_estatales_a_la_pandemia_version_4 [Accessed 7 February 2021].

CEPAL, 2020. COVID-19 Observatory for Latin America and the Caribbean: Measures by Country. Santiago de Chile: Comisión Económica para América Latina y el Caribe (CEPAL). Available from: https://www.cepal.org/en/topics/covid-19 [Accessed 7 February 2021].

CIEP, 2020. Deuda subnacional. Endeudamiento en los estados frente al COVID-19. Cuauhtémoc, Mexico City: Centro de Investigación Económica y Presupuestaria (CIEP). Available from: https://ciep.mx/deuda-subnacional-endeudamiento-en-los-estados-frente-al-covid-19/ [Accessed 7 February 2021].

CONACYT, 2020. COVID-19 Tablero México [online]. Ciudad de México: Consejo Nacional de Ciencio y Technologia (CONACYT). Available from: https://coronavirus.gob.mx/datos/ [Accessed 7 February 2021].

CONAMER, 2020. Respuestas regulatorias a la epidemia COVID-19 [online]. Ciudad de México: Comisión Nacional de Mejora Regulatoria (CONAMER). Available from: https:// conamer.gob.mx/respuestas-regulatorias-covid-19/EstadosMunicipios/Index [Accessed 7 February 2021]. 
CONAPO, 2020. Impacto de la contingencia sanitaria de Covid-19: Día Internacional de la Planificación Familiar. Ciudad de México: Consejo Nacional de Población (CONAPO). Available from: https://www.gob.mx/presidencia/es/articulos/version-estenografica-conferenciade-prensa-informe-diario-sobre-coronavirus-covid-19-en-mexico-249441?idiom=es [Accessed 7 February 2021].

CONEVAL, 2020a. Visor geoespacial de la pobreza y la COVID-19 en los municipios de México [online]. Ciudad de México: Consejo Nacional de Evaluacion de la Politica de Desarrollo Social (CONEVAL) Available from: https://coneval.maps.arcgis.com/apps/dashboards/db5c 233bb31f4c4189ded7d0edcacf92 [Accessed 7 February 2021].

CONEVAL, 2020b. La política social en el contexto de la pandemia por el virus SARSCoV-2 (COVID-19) en México. Ciudad de México: Consejo Nacional de Evaluacion de la Politica de Desarrollo Social (CONEVAL). Available from: https://www. coneval.org.mx/Evaluacion/IEPSM/Paginas/Politica_Social_COVID-19.aspx [Accessed 7 February 2021].

Excelsior, 2020. Desde hoy, suspenden clases en 10 estados [online]. Mexico City: Excelsior. 17 March 2020. Available from: https://www.excelsior.com.mx/nacional/desde-hoysuspenden-clases-en-10-estados-ante-pandemia/1370186 [Accessed 7 February 2021].

Flamand, L., 2010. Sistema federal y autonomía de los gobiernos estatales: avances y retrocesos. In: Méndez, J.L., ed. Los grandes problemas de México. Ciudad de México: El Colegio de México, 495-522.

Flamand, L., 2020. Federalism and COVID: Managing the Health and Economic Crisis in the Mexican Federation. Ottawa: Forum of Federations. Available from: http://www.forumfed. org/2020/04/laura-flamand-federalism-and-covid-19/ [Accessed 7 February 2021].

Hasell, J., Mathieu, E., Beltekian, D., Macdonald, B., Giattino, C., Ortiz-Ospina, E., Roser, M. and Ritchie, H., 2020. A Cross-Country Database of COVID-19 Testing. Scientific Data, 7 (1), 345. doi: 10.1038/s41597-020-00688-8.

IMF, 2020. Policy Responses to COVID19 [online]. Washington, DC: International Monetary Fund (IMF). Available from: https://www.imf.org/en/Topics/imf-and-covid19/PolicyResponses-to-COVID-19\#M [Accessed 8 February 2021].

INEGI, 2020a. Estimacion oportuna del Producto Interno Bruto durante el cuarto trimestre de 2020. Auguascalientes City: Instituto Nacional de Estadística y Geografía (INEGI). Available from: https://www.inegi.org.mx/contenidos/saladeprensa/boletines/2021/pib_eo/ pib_eo2021_01.pdf [Accessed 8 February 2021].

INEGI, 2020b. Encuesta Telefónica de Ocupación y Empleo 2020. Aguascalientes, Mexico: Instituto Nacional de Estadística y Geografía (INEGI). Available from: https://www.inegi. org.mx/investigacion/etoe/ [Accessed 8 February 2021].

INEGI, 2020c. Encuestra Telefónica sobre COVID-19 y Mercado Laboral. Aguascalientes, Mexico: Instituto Nacional de Estadística y Geografía (INEGI). Available from: https:// www.inegi.org.mx/investigacion/etoe/ [Accessed 8 February 2021].

INMUJERES, 2020. Violencia contra las mujeres: Indicadores básicos en tiempos de pandemia. Ciudad de México: Instituto Nacional de las Mujeres (INMUJERES). Available from: https://www.gob.mx/inmujeres/documentos/violencia-contra-las-mujeres-indicadores-entiempos-de-pandemia [Accessed 8 February 2021].

JHU, 2020. How Does Testing in the U.S. Compare to Other Countries? Baltimore: Johns Hopins University of Medicine (JHU), 2020. Available from: https://coronavirus.jhu.edu/ testing/international-comparison [Accessed 8 February 2021].

Lustig, N., Martínez-Pabon, V., Sanz, F. and Younger, S.D., 2020.The Impact of COVID-19 Lockdowns and Expanded Social Assistance on Inequality, Poverty and Mobility in Argentina, Brazil, Colombia and Mexico. Washington, DC: Center for Global Development. Available from: https://www.cgdev.org/sites/default/files/impact-covid-19lockdowns-and-expanded-social-assistance.pdf [Accessed 8 February 2021]. 


\section{Laura Flamand et al.}

Montes, J., 2021. Covid-19 Takes Outsize Toll on Mexican Health Workers; The Country Is among those with the Highest Mortality among Health Workers; 'It's Been Carnage' [online]. New York: Wall Street Journal, 9 January.

Mooney, H. and Zegarra, M.A., 2020. Extreme Outlier: The Pandemic's Unprecedented Shock to Tourism in Latin America and the Caribbean. In: Djankov, S. and Panizza, U. eds. COVID-19 in Developing Economies. London: CEPR Press, 112-126.

Najar, A., 2020. Coronavirus en México: ¿por qué AMLO enfrenta una rebelión de gobernadores en la etapa critica de la pandemia de covid-19? London: BBC News Mundo.

OECD, 2020. OECD Employment Outlook 2020: Worker Security and the COVID-19 Crisis. Paris: Organisation for Economic Cooperation and Development (OECD). doi: 10.1787/1686c758-en Available from: https://www.oecd-ilibrary.org/employment/oecdemployment-outlook-2020_1686c758-en [Accessed 8 February 2021].

Olmeda, J.C. and Armesto, A., 2017. La Recentralización y los Gobernadores: ¿Por Qué no Siempre se Oponen? Analizando el Caso de México. Ciudad de México: Foro Internacional, 227 (1), 109-148. Available from: http://www.scielo.org.mx/scielo.php?script= sci_arttext\&pid=S0185-013X2017000100109 [Accessed 8 February 2021].

Roser, M., Ritchie, H., Ortiz-Ospina, E. and Hasell, J., 2020. Coronavirus Pandemic (COVID-19) [online]. OurWorldInData.org. Available from: https:/ourworldindata.org/ coronavirus?fbclid=IwAR0GhhnIBw7H_0pKWOb4ubsuTYX52bf9O3nk6wz75w8hOjD 9SgvSO5lOs7U [Accessed 8 February 2021].

SE, 2020. La nueva normalidad: Estrategia de reapertura de las actividades sociales, educativas y económicas. Ciudad de México. Available from: https://www.cmic.org/la-nuevanormalidad/ [Accessed 8 February 2021].

SEP, 2020. Acuerdo número 02/03/20 por el que se suspenden las clases en las escuelas de educación preescolar, primaria, secundaria, normal y demás para la formación de maestros de educación básica del Sistema Educativo Nacional, así como aquellas de los tipos medio superior y superior dependientes de la Secretaría de Educación Pública. [online]. Official Journal of the Federation. Secretaría de Educación Publica (SEP): Mexico City, 2020. Available from: https://www.dof.gob.mx/nota_detalle.php?codigo $=5589479 \&$ fecha $=16 / 03 / 2020$ [Accessed 8 February 2021].

SS, 2019. Indicadores de Gasto Público en Salud 2003-2017. Mexico City: Secretaria de Salud(SS).

SS, 2020. Acuerdo por el que se establecen las medidas preventivas que se deberán implementar para la mitigación y control de los riesgos para la salud que implica la enfermedad por el virus SARS-CoV2 (COVID-19) [online]. Mexico City: Secretaria de Salud(SS), 2020. Official Journal of the Federation. Available from: https://www.dof.gob.mx/nota_detalle. php?codigo=5590339\&fecha=24/03/2020 [Accessed 8 February 2021].

WHO, 2020. Public Health Criteria to Adjust Public Health and Social Measures in the Context of COVID-19. World Health Organization (WHO): Geneva, 2020. Available from: https://apps.who.int/iris/handle/10665/332073 [Accessed 8 February 2021].

World Bank, 2020. Pandemic, Recession: The Global Economy in Crisis. In: Global Economic Prospects, June 2020. Washington DC: The World Bank. doi: 10.1596/978-1-4648-1553-9.

World Health Organization Weekly epidemiological update - 12 January 2021. Geneva: WHO, 2021. Available from https://www.who.int/publications/m/item/weekly-epidemiologicalupdate 